\title{
Assembly transport optimization for a reconfigurable flow shop based on a discrete event simulation
}

\author{
Yang, S.L. ${ }^{a, b, c, d,{ }^{*}}$, Xu, Z.G. ${ }^{a, b, c}$, Li, G.Z. ${ }^{\text {, }}$ Wang, J.Y., ${ }^{\text {a,b,c }}$ \\ ${ }^{a}$ Key Laboratory of Networked Control Systems, Chinese Academy of Sciences, Shenyang, P.R. China \\ ${ }^{b}$ Shenyang Institute of Automation, Chinese Academy of Sciences, Shenyang, P.R. China \\ 'Institutes for Robotics and Intelligent Manufacturing, Chinese Academy of Sciences, Shenyang, P.R. China \\ dUniversity of Chinese Academy of Sciences, Beijing, P.R. China \\ e'School of Mechanical Engineering and Automation, Northeastern University, Shenyang, P.R. China
}

\begin{abstract}
A B S T R A C T
Reconfigurable Manufacturing Systems (RMSs) are widely used to produce small batches of customized products in the current manufacturing environment. We comprehensively optimized the assembly transport strategy, production process, and production configuration of a reconfigurable flow shop (RFS). Firstly, three assembly transfer strategies, one-to-one, one-to-many, and many-to-many, are proposed for an RFS, given the specific process limitations. In addition, a production simulation model of the RFS is established by the Plant Simulation software to verify and compare those three strategies with realistic production constraints considered. Moreover, the production processes are optimized, and the optimal buffer configuration and vehicle configuration are optimized by the design of experiment (DOE) method. After the optimization processes, the throughput and facility utilization under each strategy increases significantly. Additionally, the optimal buffer size and vehicle quantity under each strategy are determined and compared. The one-toone strategy can maximize the production output, but it requires the most production resources. In addition, the many-to-many strategy is more efficient than the one-to-many strategy. Our study provides a variety of assembly transport strategies for an RFS and offers an efficient optimization method for production performance and production configuration.
\end{abstract}

(C) $2020 \mathrm{CPE}$, University of Maribor. All rights reserved.

\section{ARTICLE INFO}

Keywords:

Reconfigurable manufacturing

systems (RMS);

Discrete event simulation;

Assembly transport strategy;

Optimization;

Plant Simulation;

Reconfigurable flow shop;

Production configuration;

Production performance;

Simulation modelling

*Corresponding author:

yangshengluo@sia.cn

(Yang, S.L.)

Article history:

Received 13 December 2019

Revised 16 March 2020

Accepted 18 March 2020

\section{References}

[1] Bortolini, M., Galizia, F.G., Mora, C. (2018). Reconfigurable manufacturing systems: Literature review and research trend, Journal of Manufacturing Systems, Vol. 49, 93-106, doi: 10.1016/i.jmsy.2018.09.005.

[2] Esmaeilian, B., Behdad, S., Wang, B. (2016). The evolution and future of manufacturing: A review, Journal of Manufacturing Systems, Vol. 39, 79-100, doi: 10.1016/j.jmsy.2016.03.001.

[3] Koren, Y., Heisel, U., Jovane, F., Moriwaki, T., Pritschow, G., Ulsoy, G., Van Brussel, H. (1999). Reconfigurable manufacturing systems, CIRP Annals, Vol. 48, No. 2, 527-540, doi: 10.1016/S0007-8506(07)63232-6.

[4] Dou, J.-P., Dai, X.-Z., Meng, Z.-D. (2007). Configuration selection of reconfigurable manufacturing system based on hybrid analytical hierarchy process, Computer Integrated Manufacturing Systems, Vol. 13, No. 7, 1360-1366.

[5] Gupta, A., Jain, P.K., Kumar, D. (2015). Configuration selection of reconfigurable manufacturing system based on performance, International Journal of Industrial and Systems Engineering, Vol. 20, No. 2, 209-230, doi: 10.1504/IJISE.2015.069543.

[6] Rehman, A.-U., Subash Babu, A. (2009). Evaluation of reconfigured manufacturing systems: An AHP framework, International Journal of Productivity and Quality Management, Vol. 4, No. 2, 228-246, doi: 10.1504/IJPQM.2009. $\underline{023189 .}$. 
[7] Amiri, M., Mohtashami, A. (2012). Buffer allocation in unreliable production lines based on design of experiments, simulation, and genetic algorithm, The International Journal of Advanced Manufacturing Technology, Vol. 62, No. 1-4, 371-383, doi: 10.1007/s00170-011-3802-8.

[8] Huang, L., Gao, Y., Qian, F., Tang, S., Wang, D. (2011). Configuration selection for reconfigurable manufacturing systems by means of characteristic state space, Chinese Journal of Mechanical Engineering, Vol. 24, No. 1, 23-32, doi: 10.3901/CJME.2011.01.023.

[9] Youssef, A.M.A., ElMaraghy, H.A. (2008). Availability consideration in the optimal selection of multiple-aspect RMS configurations, International Journal of Production Research, Vol. 46, No. 21, 5849-5882, doi: 10.1080/0020 $\underline{7540701261626 .}$

[10] Youssef, A.M.A., ElMaraghy, H.A. (2007). Optimal configuration selection for reconfigurable manufacturing systems, International Journal of Flexible Manufacturing Systems, Vol. 19, No. 2, 67-106, doi: 10.1007/s10696007-9020-X.

[11] Zhang, Z., Wang, X., Wang, X., Cui, F., Cheng, H. (2019). A simulation-based approach for plant layout design and production planning, Journal of Ambient Intelligence and Humanized Computing, Vol. 10, No. 3, 1217-1230, doi: $10.1007 / \mathrm{s} 12652-018-0687-5$.

[12] Negahban, A., Smith, J.S. (2014). Simulation for manufacturing system design and operation: Literature review and analysis, Journal of Manufacturing Systems, Vol. 33, No. 2, 241-261, doi: 10.1016/i.jmsy.2013.12.007.

[13] Azadeh, A., Nokhandan, B.P., Asadzadeh, S.M., Fathi, E. (2011). Optimal allocation of operators in a cellular manufacturing system by an integrated computer simulation-genetic algorithm approach, International Journal of Operational Research, Vol. 10, No. 3, 333-360, doi: 10.1504/IJOR.2011.038905.

[14] Huang, C.-J., Chang, K.-H., Lin, J.T. (2012). Optimal vehicle allocation for an automated materials handling system using simulation optimisation, International Journal of Production Research, Vol. 50, No. 20, 5734-5746, doi: 10.1080/00207543.2011.622311.

[15] Michalos, G., Makris, S., Mourtzis, D. (2012). An intelligent search algorithm-based method to derive assembly line design alternatives, International Journal of Computer Integrated Manufacturing, Vol. 25, No. 3, 211-229, doi: 10.1080/0951192X.2011.627949.

[16] Staley, D.R., Kim, D.S. (2012). Experimental results for the allocation of buffers in closed serial production lines, International Journal of Production Economics, Vol. 137, No. 2, 284-291, doi: 10.1016/j.ijpe.2012.02.011.

[17] Um, I., Cheon, H., Lee, H. (2009). The simulation design and analysis of a flexible manufacturing system with automated guided vehicle system, Journal of Manufacturing Systems, Vol. 28, No. 4, 115-122, doi: 10.1016/i.jmsy. 2010.06.001.

[18] Gyulai, D., Pfeiffer, A., Kádár, B., Monostori, L. (2016). Simulation-based production planning and execution control for reconfigurable assembly cells, Procedia CIRP, Vol. 57, 445-450, doi: 10.1016/j.procir.2016.11.077.

[19] Di Gironimo, G., Lanzotti, A., Peluso, F., Renno, F. (2015). Virtual production planning of a high-speed train using a discrete event simulation based approach, International Journal on Interactive Design and Manufacturing, Vol. 9, No. 1, 65-75, doi: 10.1007/s12008-013-0193-0.

[20] Leitão, P., Mendes, J.M., Bepperling, A., Cachapa, D., Colombo, A.W., Restivo, F. (2012). Integration of virtual and real environments for engineering service-oriented manufacturing systems, Journal of Intelligent Manufacturing, Vol. 23, 2551-2563, doi: 10.1007/s10845-011-0591-8.

[21] Rifai, A.P., Dawal, S.Z.M., Zuhdi, A., Aoyama, H., Case, K. (2016). Reentrant FMS scheduling in loop layout with consideration of multi loading-unloading stations and shortcuts, The International Journal of Advanced Manufacturing Technology, Vol. 82, No. 9-12, 1527-1545, doi: 10.1007/s00170-015-7395-5.

[22] Subulan, K., Cakmakci, M. (2012). A feasibility study using simulation-based optimization and Taguchi experimental design method for material handling - Transfer system in the automobile industry, The International Journal of Advanced Manufacturing Technology, Vol. 59, No. 5-8, 433-443, doi: 10.1007/s00170011-3514-0.

[23] Renna, P., Ambrico, M. (2015). Design and reconfiguration models for dynamic cellular manufacturing to handle market changes, International Journal of Computer Integrated Manufacturing, Vol. 28, No. 2, 170-186, doi: 10.1080/0951192X.2013.874590.

[24] Andrade-Gutierrez, E.S., Carranza-Bernal, S.Y., Hernandez-Sandoval, J., Gonzalez-Villarreal, A.J., Berber-Solano, T.P. (2018). Optimization in a flexible die-casting engine-head plant via discrete event simulation, The International Journal of Advanced Manufacturing Technology, Vol. 95, No. 9-12, 4459-4468, doi: 10.1007/ s00170-017-1562-9.

[25] Ištoković, D., Perinić, M., Doboviček, S., Bazina, T. (2019). Simulation framework for determining the order and size of the product batches in the flow shop: A case study, Advances in Production Engineering \& Management, Vol. 14, No. 2, 166-176, doi: 10.14743/apem2019.2.319.

[26] Yang, S.L., Xu, Z.G., Wang, J.Y. (2019). Modelling and production configuration optimization for an assembly shop, International Journal of Simulation Modelling, Vol. 18, No. 2, 366-377, doi: 10.2507/IJSIMM18(2)C010.

[27] Supsomboon, S., Varodhomwathana, T. (2017). Robot and plant simulation for automotive part production process design: A case study, International Journal of Simulation Modelling, Vol. 16, No. 4, 617-629, doi: $10.2507 /$ IJSIMM16(4)5.397.

[28] García-Montalvo, O., Hernández-Sandoval, J., Haro-Rodríguez, S., Berber-Solano, T.P., Bello-Gómez, M.A., SalasZamarripa, A., Sáenz-Valdez, A.A., Talamantes-Silva, J. (2019). Discrete-event modeling for the design of a sand recovery flexible pilot plant in the casting process, The International Journal of Advanced Manufacturing Technology, Vol. 103, No. 9-12, 4703-4711, doi: 10.1007/s00170-019-03957-y.

[29] Malega, P., Kadarova, J., Kobulnicky, J. (2017). Improvement of production efficiency of tapered roller bearing by using plant simulation, International Journal of Simulation Modelling, Vol. 16, No. 4, 682-693, doi: $\underline{10.2507 / I J S I M M 16(4) 10.405 . ~}$ 
[30] Fedorko, G., Molnár, V., Honus, S., Neradilová, H., Kampf, R. (2018). The application of simulation model of a milk run to identify the occurrence of failures, International Journal of Simulation Modelling, Vol. 17, No. 3, 444-457, doi: $10.2507 / I J S I M M 17(3) 440$. 


\title{
APEM
}

\section{Optimizacija transporta pri montaži znotraj rekonfigurabilne proizvodne linije na podlagi simulacije diskretnih dogodkov}

\author{
Yang, S.L. ${ }^{a, b, c, d,{ }^{*}}$, Xu, Z.G. ${ }^{a, b, c}$, Li, G.Z. ${ }^{\text {, }}$ Wang, J.Y. ${ }^{a, b, c}$ \\ ${ }^{a}$ Key Laboratory of Networked Control Systems, Chinese Academy of Sciences, Shenyang, P.R. China \\ ${ }^{b}$ Shenyang Institute of Automation, Chinese Academy of Sciences, Shenyang, P.R. China \\ ${ }^{c}$ Institutes for Robotics and Intelligent Manufacturing, Chinese Academy of Sciences, Shenyang, P.R. China \\ dUniversity of Chinese Academy of Sciences, Beijing, P.R. China \\ ${ }^{e}$ School of Mechanical Engineering and Automation, Northeastern University, Shenyang, P.R. China
}

\section{POVZETEK}

Rekonfigurabilni proizvodni sistemi (RMS) se pogosto uporabljajo za izdelavo majhnih serij prilagojenih izdelkov v trenutnem proizvodnem okolju. Izčrpno smo optimizirali transportno strategijo pri montaži, proizvodni proces in proizvodno konfiguracijo velike rekonfigurabilne proizvodne linije (RFS). Najprej so za RFS predlagane tri strategije prenosa sklopov, ena-na-ena, enana-mnogo in mnogo-na-mnogo, glede na posebne omejitve postopka. V programski opremi Plant simulation smo vzpostavili simulacijski model RFS za preverjanje in primerjavo teh treh strategij z upoštevanimi realnimi proizvodnimi omejitvami. Poleg tega smo proizvodne procese optimizirani, optimalna konfiguracija zalogovnika in konfiguracija vozila pa sta bili optimizirani z metodo zasnove eksperimenta (DOE). Po optimizaciji sta se pretočnost in izkoriščenost objekta pri vsaki strategiji znatno povečata. Poleg tega smo določili in primerjali optimalno velikost zalogovnika in število vozil za vsako strategijo. Strategija ena-na-ena lahko poveča proizvodnjo, vendar zahteva največ proizvodnih virov. Poleg tega je strategija mnogo-na-mnogo učinkovitejša od strategije ena-na-mnogo. Naša študija je obravnavala različne strategije transporta pri montaži za RFS in ponudila učinkovito optimizacijsko metodo za povečanje zmogljivosti in izboljšanje konfiguracije proizvodnje.

(C) 2020 CPE, University of Maribor. All rights reserved.

\section{PODATKI O ČLANKU}

Ključne besede:

Rekonfigurabilni proizvodni sistem (RMS);

Simulacija diskretnih dogodkov;

Strategija transporta pri montaži; Optimizacija;

Plant simulation;

Velika rekonfigurabilna proizvodna linija;

Konfiguracija proizvodnje;

Zmogljivost proizvodnje;

Simulacijsko modeliranje

*Kontaktna oseba:

yangshengluo@sia.cn

(Yang, S.L.)

Zgodovina članka:

Prejet 13. decembra 2019

Popravljen 16. marca 2020

Sprejet 18. marca 2020 